\title{
Ardahan İli 2018 Yılı Arkeolojik Yüzey Araştırması: Genel Değerlendirme
}

\section{Archaeological Survey in Ardahan in 2018: A General Evaluation}

\author{
Sami Patac1 ${ }^{\mathrm{a},{ }^{*},}$, Sinan Altun ${ }^{\mathrm{b}}$ \\ ${ }^{a}$ Dr. Öğr. Üyesi, Ardahan Üniversitesi, İnsani Bilimler ve Edebiyat Fakültesi, Arkeoloji Bölümü, 75000, Ardahan/Türkiye. \\ ORCID: 0000-0003-1840-6562

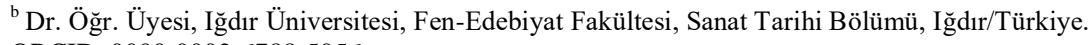 \\ ORCID: 0000-0002-6788-5056
}

\section{MAKALE BILGISII}

Makale Geçmişi

Başvuru tarihi: 10 Temmuz 2020

Düzeltme tarihi: 17 Ekim 2020

Kabul tarihi: 23 Ekim 2020

Anahtar Kelimeler:

Ardahan,

Kaleler,

Kuleler,

Demir Çağı,

Ortaçağ
ÖZ

Ardahan'da 2018 yılında gerçekleştirilen arkeolojik araştırmaların sonuçları bu çalışmanın konusunu oluşturmaktadır. Araştırmalarımız il merkezinde ve Göle ilçesinde yoğunlaştırılmıştır. $\mathrm{Bu}$ araştırmalar merkez ilçedeki Çağlayık ve Bağdaşan, Göle'deki Bellitepe, Balçeşme ve Durucasu yerleşimlerinin yakın çevresine odaklanmıştır. Yerleşimlerin hemen yakınında Demir Çağı ve Orta Çağ'dan kalma çok sayıda yeni keşfedilen arkeolojik alan tespit edilmiştir. 2018 y1lında merkez ilçede belgelenen en önemli arkeolojik buluntular Bayramoğlu'ndaki kaledir. Bu arkeolojik alan, bölgedeki Antik Çağ savunma yapılarının tipolojisi hakkında yeni veriler sağlamaktadır. Genel olarak Göle'deki arkeolojik alanlar, şehir merkezine ve Çıldır'a göre daha fazla sayıda Demir Çağı seramik buluntu barındırması bakımından farklılık gösterir. Ne var ki 2018 saha araştırmasında araştırma ekibimiz çok sayıda Ortaçağ seramik örneklerini de tespit etmiştir. Özellikle Göle'deki Balçeşme ve Durucasu civarındaki arkeolojik alanlar 2018 yılının en önemli keşifleri olmuşlardır.

\section{A B S T R ACT}

The results of the archaeological researches conducted in Ardahan between the year 2018 constitute the subject of this paper. Our surveys were conducted in the central district and in Göle in Ardahan. These researches were focused on the modern settlements of Çağlayık and Bağdaşan in the central district, Bellitepe, Balçeşme and Durucasu in Göle. A large number of new discovered archaeological sites dating back to the Iron and middle Ages have been identified in the immediate vicinity of these settlements. The most important archaeological finds documented in the central district in 2018 is the fortress in Bayramoğlu. This site have provided a new datum on the typology of the defense structures in Antiquity. Actually The archaeological sites in Göle differ in terms of containing more numbers of pottery finds from Iron age compared to the city center and Ç1ldır. But in 2018 field survey our research team detected much numbers of Medieval pottery fragments too. Especially near the vicinity of Balçeşme and Durucasu in Göle was the most important archaeological ruins discovered in 2018.

\section{Giriş}

Ardahan İli 2018 Yılı Yüzey Araştırması Eylül ayında gerçekleştirilmiştir. Araştırmamıza Dr. Öğr. Üyesi Nazlı Yıldırım, Dr. Araş. Görevlisi İsaf Bozoğlu Bay, Atatürk Üniversitesi Arkeoloji bölümü doktora programı öğrencileri Elif Yavuz, Serdal Gündoğdu ve Araş. Gör. Sinem Coşkun katılmışlardır.
2018 yılı yüzey araştırması ilin merkez ve Göle ilçelerinde gerçekleştirilmiştir. Yüzey araştırmamıza çok önemli katkılarda bulunan ve çalışmalarımızın doğru ve daha kolay gerçekleşmesini sağlayan bakanlık temsilcisi sayın Günay Yeğen'e araştırma ekibimiz adına ayrıca teşekkür ederiz. Toplam altı sezonluk yüzey araştırmalarımız süresince tüm bakanlık temsilcilerimizin yaptığımız çalışmalara çok önemli katkıları olmuştur. 2018 yılı yüzey

\footnotetext{
*Sorumlu yazar/Corresponding author.

e-posta: samipataci@hotmail.com
} 
araştırmamız Ardahan'da gerçekleștirdiğimiz son arkeolojik yüzey araştırması olmuştur.

\section{Merkez İlçe Buluntuları:}

2018 yılında ilin merkez ilçesinde tespit edilen arkeolojik alanlar şöyledir: Çağlayık-Doğu Savunma Yapısı, Çağlayık-Kuzeydoğu Kalesi, Bayramoğlu Kalesi ve Bağdaşan Savunma Yapısı.

\section{1. Çağlayık-Doğu Savunma Yapısı (Harita 1; Resim 1-2)}

Çağlayık köyü, il merkezinin karayolu ile yaklaşı 35 km kadar güneydoğusunda yer alan Hasköy bucağına bağlı bir yerleşimdir. Çağlayık'ın kuşbakışı yaklaşık $900 \mathrm{~m}$ doğusunda ve $1.3 \mathrm{~km}$ kuzeydoğusunda olmak üzere iki ayrı arkeolojik alan tespit edilmiştir. Aralarında $800 \mathrm{~m}$ kadar bir mesafe olan ve iki ayrı tepe üzerinde bulunan bu kalıntılar büyük olasılıkla askerî amaçlı yapılmışlardır.

Köyün doğusunda yer alan arkeolojik alan, ortalama 21802190 m rakımları arasında olup bir tepenin kuzeye bakan zirvesinde yer alır. (Koordinatlar: 41 ${ }^{\circ} 2^{\prime} 39.82^{\prime \prime} \mathrm{K}$ 4256'35.50"D; 41 2'38.98"K 4256'34.06"D). Burada, arazi koşullarına göre inşa edilmiş bir yapı, köşeleri yuvarlak, dörtgene yakın bir plana sahiptir. Doğu-batı doğrultusunda $50 \mathrm{~m}$; kuzey-güney doğrultusunda ise $42 \mathrm{~m}$ boyutlarında bir alanı kaplayan bu yapıdan, büyük ölçüde yıkılmış duvarlara ait bir moloz yığını kalmıştır. Yapının kuzey kenarı, tepenin yamacına doğru inşa edildiği için bu kenar güney kenarına oranla birkaç metre daha düşük seviyededir. Yapının günümüze kadar korunmayı başarmış duvarları alanın güney ve güneybatısında gözlemlenmektedir ve anlaşıldığı kadarıyla yapının tahrip olmuş girişi de güney kenarda yer almaktaydı. Kuru duvar tekniğinde orta ve büyük boyutlu taşlardan inşa edilmiş duvarlar arazi seviyesinde korunmuştur. Ölçülebilen in situ duvarların maksimum uzunluğu $12 \mathrm{~m}$ kadardır. Duvar kalınlığı ise $1.60 \mathrm{~m}$ civarındadır. Bazaltik yapı taşları arasında en büyük boyutlu olanı, yapının güney kenarında olup 3.40 × $2.20 \mathrm{~m}$ boyutlarındadır. Ancak genel itibariyle yapı taşları orta boyuttadır. Kura Nehri'ne bağlı bir derenin $200 \mathrm{~m}$ güneydoğusunda yer alan ve küçük bir askerî karakol işlevinde kullanılmış olması muhtemel olan bu yapı kalıntısında ve yakın çevresinde, tarihlemeye katkı sağlayacak herhangi bir küçük buluntu tespit edilememiştir. Mimari özellikleri itibariyle ele alındığında Erken Demir Çağı özelliği gösterse de yapının ilk inşa tarihi hakkında kesin bir yorum yapabilmek mümkün değildir.

\section{2. Çağlayık-Kuzeydoğu Kalesi (Harita 1; Resim 3- 4)}

Çağlayık köyündeki diğer bir arkeolojik alan, yukarıda da bahsedildiği gibi köyün 1,3 km kuzeydoğusundaki $2240 \mathrm{~m}$ rakımlı bir tepenin zirvesinde ve doğu sinırında yer almaktadır (Koordinatlar: 41 ${ }^{\circ} 3^{\prime} 4.20^{\prime \prime} \mathrm{K}$ 42 $2^{\circ} 6^{\prime} 46.85^{\prime \prime D}$; $41^{\circ} \quad 3^{\prime} 3.63^{\prime \prime K} \quad 42^{\circ} 56^{\prime} 47.39^{\prime \prime} \mathrm{D} ; \quad 41^{\circ} \quad 3^{\prime} 4.94 " \mathrm{~K}$ $\left.42^{\circ} 56^{\prime} 47.93 " D\right)$. Çağlayık'ın doğusundaki yapı kalıntısına göre daha yüksek bir seviyede yer alan bu yapının duvarları diğerine göre daha sağlam korunmuştur. Her iki yap1 da $800 \mathrm{~m}$ mesafede birbirini görür şekilde konumlanmaktadır. Kuru duvar tekniğinde orta ve büyük boyutlu taşlarla inşa edildiği anlaşılan yapı, orta boyutlu bir kale işlevinde kullanılmış olmalıdır. Kuzey-güney yönünde akan Kura Nehri'ne bağlı derenin kuşbakışı 140 m kadar batısındaki kale, çevreye hâkim bir konumdadır.

Kuzeydoğu-güneybatı doğrultusunda inşa edilmiş yapının ölçüleri 39 x 34 m'dir. Beşgen planlı yapı üç bölüme ayrılmaktadır. Yapının ana güney bölümünün iç ölçüleri maksimum 38 x 24 m'dir. Kuzey kenarda yer alan daha küçük boyutlu ve bitişik inşa edilmiş diğer iki mekânın iç ölçüleri bu noktada kötü durumda korunmuş duvarlardan anlaşılabildiği kadarıyla $5 \times 8 \mathrm{~m}$ ve $8.5 \times 9 \mathrm{~m}$ civarındadır. Ana bölümün ayrıca kendi içinde farklı mekanlara sahip olduğu da temel seviyesinde ve kötü durumda korunmuş yapı kalıntılarından az çok anlaşılabilmektedir. Yapının giriş bölümü tespit edilememiştir ancak muhtemelen yapıya giriş güney kenardan sağlanmaktaydı. Kale duvarlarının kalınlıkları 1.60 ilâ $2.50 \mathrm{~m}$ arasında değişmektedir. Yapı duvarları arazi seviyesinden 1-1.5 m civarı yükseklikte korunabilmiştir.

Çağlayık Kuzey Kalesi’nin batı kenarının hemen dışındaki arazi üzerinde kare ve dikdörtgen planlı bir yap1 grubu daha vardır. 6-8 mekândan oluştuğu anlaşılan bu bitişik inşa edilmiş mimari birimler, temel seviyesinde korunabilmiştir. Aynı şekilde, kalenin kuzeyindeki alanda da yapılaşma olduğu anlaşılsa da buradaki yapı kalıntısı çok daha kötü durumda korunmuştur. Kalenin kuzeydoğu kenarına bitişik inşa edilmiş 11 x $9.5 \mathrm{~m}$ boyutlarındaki dikdörtgen planlı bir başka mekan, tepenin yamacında yer aldığ 1 için kaleye göre birkaç metre daha aşağı seviyededir. Tüm mimari kalıntılarla birlikte arkeolojik alanın boyutları 65 x 55 m kadardır. Bu mekanların işlevinin tam olarak anlaşılabilmesi için arkeolojik bir kazı yapılması gerekmektedir. Alanda yapılan araştırmalar sırasında genel olarak Demir Çağı ve az sayıda Ortaçağ seramik parçaları tespit edilmiştir.

\subsection{Bayramoğlu Kalesi (Harita 1; Resim 5-10)}

Hasköy Bucağına bağlı Bayramoğlu köyü, il merkezinin karayoluyla $39 \mathrm{~km}$ güneydoğusunda yer almaktadır. Bu köyün $3 \mathrm{~km}$ güneydoğusunda Demir Çağı'na ait olması gereken bir kale, araştırma ekibimizce tespit edilmiştir (Koordinatlar: $\quad 40^{\circ} 57^{\prime} 49.52^{\prime \prime} \mathrm{K} \quad 42^{\circ} 58^{\prime} 53.63^{\prime \prime} \mathrm{D}$; $40^{\circ} 57^{\prime} 50.75^{\prime \prime} \mathrm{K} \quad 42^{\circ} 58^{\prime} 55.48^{\prime \prime} \mathrm{D} ; \quad 40^{\circ} 57^{\prime} 49.10^{\prime \prime} \mathrm{K}$ $42^{\circ} 58^{\prime} 56.56^{\prime \prime} \mathrm{D} ; \quad 40^{\circ} 57^{\prime} 47.32^{\prime \prime} \mathrm{K} \quad 42^{\circ} 58^{\prime} 52.92^{\prime \prime} \mathrm{D}$; $40^{\circ} 57^{\prime} 48.72^{\prime \prime K} 42^{\circ} 58^{\prime} 51.75^{\prime \prime D)}$. Bayramoğlu Kalesi, 2330 $\mathrm{m}$ rakımdaki bir yükseltinin teraslanmış zirvesinde ve sağlam bir kayalık zemin üzerinde yükselmektedir. Orta ve yer yer büyük boyutlu bazalt taşların üst üste bindirilmesiyle kuru duvar tekniğinde inşa edilen kalenin, ilk inşa edildiği dönemde $60 \times 60 \mathrm{~m}$ boyutlarında kare planlı bir savunma yapısı olması gerekmektedir. Ancak insan eliyle yakın dönemlerde yapılan tahribat sebebiyle kalenin tam planı kesinleştirilememiştir. Günümüze kadar yöre sakinlerince hayvancılık faaliyetleri doğrultusunda kullanıldığı anlaşılan kaleye ait duvar taşları alınıp burada farklı bölümlere ayrılan ağıllar oluşturulmuştur. Kaleden alınan taşlarla, yapının kuzeyindeki teras üzerine ve kaleye bitişik olarak, taşların özensizce üst üste bindirilmesiyle oluşturulmuş 65 x $51 \mathrm{~m}$ boyutlarında, tek sıra cılız bir çevre duvarı sonradan yapılmıştır. Bunun yanında, kalenin içi de yine sonradan örülmüş alçak seviyeli modern duvarlarla üç bölüme ayrılmıştır. 
Kuzeybat1-güneydoğu doğrultusunda konumlanan kalenin, özellikle kuzeydoğu ve güneydoğu duvarları nispeten iyi derecede korunabilmiştir. Savunma açısından oldukça sağlam yapıldığı anlaşılan kale duvarlarının kalınlığ 2.50 $\mathrm{m}$ ile $3.70 \mathrm{~m}$ arasında değişmektedir. Neredeyse $4 \mathrm{~m}$ kalınlığa varan duvarlar, özellikle kalenin kuzeyinde yer alan ve $2.10 \mathrm{~m}$ genişliğe sahip giriş bölümünde çok daha iyi korunmuş durumdadır. Kale duvarlarının maksimum korunan yüksekliği tam bu noktada 3.30 m'dir. Kalenin batı ve Kuzey sınırlarında bir-iki metre uzunlukta korunabilmiş duvarlar dışında, yapının kuzey ve batı kenarlarında savunma duvarı yoktur. Yapının özellikle kuzey sınırı doğal kayalıktır ve bu kayalık yapının çevresindeki arazi seviyesinden 5-10 m daha yüksektedir. Yapının batısında ve güneyindeki geniş arazide doğu-batı doğrultusunda uzanan kurumuş dere yatakları, muhtemelen kalenin su ihtiyacını geçmişte karşılamaktaydı. Ayrıca kale ile Bayramoğlu köyü arasında Kura Nehri'ne bağlı bir dere, doğu-batı doğrultusunda akmaktadır. Kalede ve kalenin yakın çevresinde yapılan araştırmalarda Demir Çağı ve Ortaçağ seramik buluntuları tespit edilmiştir. Bayramoğlu Kalesi'nin ilk inşa tarihinin Demir Çağı olması gerekmektedir.

\subsection{Bağdaşan Savunma Yapısı (Harita 1; Resim 11-} 13)

Bağdaşan köyü il merkezinin yaklaşık $30 \mathrm{~km}$ batısında yer almaktadır. Bağdaşan köyünün $1.5 \mathrm{~km}$ kadar batısında, askerî işlevde kullanılmış olması gereken bir yapı kalıntısı yer almaktadır. Ardahan-Ardanuç karayolunun $70 \mathrm{~m}$ kuzeyinde konumlanan bu arkeolojik alan kayalık bir tepecik üzerindedir. Tepeciğin kuzey kenarında doğu-batı doğrultusunda oval formlu ilerleyen bir in situ duvar, $27 \mathrm{~m}$ boyunca aralıklarla takip edilebilmektedir. Kuru duvar tekniğinde inşa edilmiş bu yapının temel seviyesinde korunan kuzey duvarı ve batı sınırda bir-iki metre korunabilmiş bir temel dışında, diğer duvarlarından günümüze hiçbir kalıntı kalmamıştır. $\mathrm{Bu}$ yapı ve yakın çevresinde çok sayıda Ortaçağ seramiği gözlemlenmiştir (Koordinatlar: $\left.41^{\circ} 3^{\prime} 57.60^{\prime \prime} \mathrm{K} 42^{\circ} 21^{\prime} 54.70 " \mathrm{D}\right)$.

\section{Göle İlçesi Buluntuları}

2018 yılı arkeolojik yüzey araştırmalarımız sırasında İlin güneyindeki Göle ilçesinde altı farklı arkeolojik alan tespit edilmiştir. Bunlar, Bellitepe Kalesi, Balçeşme-Kayınlık Kulesi, Balçeşme-Şipşirik Kulesi, Balçeşme Tekmezar Kulesi ve Yerleşimi, Balçeşme-Çam Ormanı Eskiçă̆ Arkeolojik Alanı ve Durucasu-Şimşimik Kalesi'dir.

\subsection{Bellitepe Kalesi (Resim 14-15)}

2018 yılında belgelenen arkeolojik buluntular arasında yer alan Bellitepe Kalesi, aynı adlı köyün 550 m kuzeyindedir (Koordinatlar: $\quad 40^{\circ} 55^{\prime} 16.42^{\prime \prime} \mathrm{K} \quad 42^{\circ} 32^{\prime} 31.47^{\prime \prime D}$; $40^{\circ} 55^{\prime} 15.54^{\prime \prime} \mathrm{K} \quad 42^{\circ} 32^{\prime} 33.30^{\prime \prime} \mathrm{D} ; \quad 40^{\circ} 55^{\prime} 14.23 " \mathrm{~K}$ $\left.42^{\circ} 32^{\prime} 32.26^{\prime \prime} \mathrm{D} ; 40^{\circ} 55^{\prime} 15.07^{\prime \prime K} 42^{\circ} 32^{\prime} 30.18^{\prime \prime D}\right)$. Esasinda bu yap1 ilk olarak 2017 yılında keşfedilse de alandaki çalışmalar 2018 yılında gerçekleştirilebilmiştir. Kuzupınarı ile Bellitepe köyleri sinırlarında, doğu-batı doğrultusunda aralıklarla konumlanan iki kale ve iki kule yapısının varlığı rastlantı olmamalıdır. Bu nedenle mutlaka bu bölgede çok daha kapsamlı arkeolojik çalışmaların yapılması gerekmektedir. Göle'nin bu bölgesindeki geniş ovanın kuzeyi ve güneyindeki yükseltilerde 2016-2018 yılları arasında altı farklı arkeolojik alanda çalışma gerçekleştirilmiştir. Ovanın güney merkezindeki Dedeşen (Gümüşparmak) Höyüğü ise savunma duvarları, kilisesi, mezarlığı ve diğer kalıntılarıyla Ardahan'ın en önemli Ortaçağ arkeolojik alanlarındandır.

Bellitepe Kalesi, 2214 m rakımdaki bir tepenin zirvesinde inşa edilmiş kare planlı bir Eskiçağ kalesidir. Kuzeydoğugüneybatı doğrultusunda konumlanan kalenin boyutları 55 x 53 m'dir. Orta ve küçük boyutlu taşlarla kuru duvar tekniğinde inşa edilen kalenin duvarları maksimum $1.10 \mathrm{~m}$ yükseklikte korunabilmiştir. Duvar kalınlıkları ise $2.10 \mathrm{~m}$ ile $2.36 \mathrm{~m}$ arasında değişmektedir. Kale duvarları haricinde, yapının özellikle kuzey duvarının 10 m kadar ilerisinde gözlemlenebilen bir çevre duvarı daha bulunmaktadır. Yapının doğu kenarının dışındaki arazide ise farklı mimari yapılara ait temel seviyesinde korunmuş izler gözlemlenebilmektedir. Ancak bu nokta oldukça tahrip durumdadır. Ayrıca, kalenin hem içinde hem de güneyindeki arazide yine temel seviyesinde korunmuş kare ve dikdörtgen planlı yapılarda arazi seviyesinde tespit edilmiştir. Ne var ki bu kalıntılar da oldukça kötü derecede korunmuştur ve işlevleri hakkında bir yorum getirebilmek şu an için kolay değildir. Belki de tıpkı Kuzupınarı'nda olduğu gibi burada da kaleye bağlı mevsimlik bir Eskiçağ yerleşimi bulunmaktaydı. Bellitepe Kalesi ve yakın çevresinde yaptığımız gözlemler sırasında kalenin tarihlenmesine katkıda bulunabilecek herhangi bir küçük buluntu tespit edilememiştir. Kalenin Eskiçağ içlerinde hangi döneme ait olduğunu kestirebilmek için arkeolojik bir kazı yapılması gerekmektedir. Bu bölgedeki savunma yapıları Demir Çağı'na tarihlenmektedir. Kalenin bu döneme ait olması muhtemeldir.

\subsection{Balçeșme-Kayınlık Kulesi (Harita 1; Resim 16-} 19)

Balçeşme köyü, Göle ilçe merkezinin $21 \mathrm{~km}$ kuzeydoğusunda yer almaktadır. $\mathrm{Bu}$ köyün $3.2 \mathrm{~km}$ kuzeybatısında bir Demir Çağı kulesi 2018 yılı çalışmalarında belgelenmiştir (Koordinatlar: 4051'10.69"K 4248'19.86"D). Kayınlık Deresi’nin hemen $50 \mathrm{~m}$ ve modern karayolunun ise $25 \mathrm{~m}$ kadar kuzeyindeki kule, az işçilikli ve orta boyutlu taşlarla kuru duvar tekniğinde inşa edilmiştir. Bu askeri yapı, doğu-batı doğrultusunda uzanan vadinin kuzey kenarındaki $2125 \mathrm{~m}$ rakıma sahip bir yükseltide yer almakta ve kuzeydoğugüneybatı doğrultusunda konumlanmaktadır. Bu nokta, esasında vadiden kuzeye doğru gittikçe yükselen büyük bir yükseltinin güney sınırındaki kayalık ve alçak bir seviyededir. Vadinin güneyi ise $5.6 \mathrm{~km}$ boyunca doğu-batı doğrultusunda uzanan ormanlık bir alandır. Kule plan olarak, doğu ve batı kenarlarından basık, yarım yuvarlak bir görünüme sahiptir. Yapının güney kenarında bir duvar kalıntısı tespit edilememiştir. Karayolu ve Kayınlık Deresi'ne bakan tepeciğin bu kenarı, doğal kayalıktır. Balçeşme-Kayınlık Kulesi, planı itibariyle Bellitepe-Doğu Kulesi ile benzeşmektedir; ancak Balçeşme Kulesi Bellitepe'dekine oranla çok daha iyi korunmuş durumdadır. 18 x 16.5 m'lik bir alanı kaplayan BalçeşmeKayınlık Kulesi'ni, güney yönü haricinde diğer yönlerde ayrıca bir çevre duvarı sarar. Bu çevre duvarı da kule ile aynı duvar işçiliğinde inşa edilmiştir. Çevre duvarıyla birlikte arkeolojik alan 31 x 26 m'lik bir alanı 
kaplamaktadır. Kule duvarlarının korunan maksimum yüksekliği en iyi korunan kuzey duvarında 2.22 m'dir. Duvar kalınlıkları 2.5-3 m arasında değişmektedir. Balçeşme-Kayınlık Kulesi ve çevresinde 10.-13. yüzyıllar arasına ait olması gereken çok sayıda Ortaçağ seramiği tespit edilmiştir. Mimari yapı açısından Demir Çağı özellikleri gösteren bu yapı muhtemelen Ortaçağ içlerinde de kullanılmış olmalıdır.

\subsection{Balçeşme-Şipşirik Kulesi (Harita 1; Resim 20-} 21)

Balçeşme köyünün $1,6 \mathrm{~km}$ güneyinde, kuzey-güney yönünde uzanan vadinin batı kenarındaki $2220 \mathrm{~m}$ rakımlı bir tepenin zirvesinde, 9.20 × $7.80 \mathrm{~m}$ ölçülerinde büyük ölçüde tahrip olmuş bir gözetleme kulesinin kalıntıları, Göle ilçesinde belgelenen yapılar arasındadır (Koordinatlar: $\quad 40^{\circ} 48^{\prime} 59.64^{\prime \prime} \mathrm{K} \quad 42^{\circ} 49^{\prime} 30.64^{\prime \prime} \mathrm{D}$; $\left.40^{\circ} 48^{\prime} 56.91 " \mathrm{~K} \quad 42^{\circ} 49^{\prime} 31.43^{\prime \prime D}\right)$. Bu kule, yükseltinin karayolu ve Şipşirik Deresi'ne bakan sarp yamacının tam sınırında yer almaktadır. Yapının vadiye hâkim şekilde konumlandırılması $4.5 \mathrm{~km}$ kuzeyde yer alan BalçeşmeKayınlık Kulesi'nin konumlandırılışı ile oldukça benzerdir. Şipşirik Deresi, gözetleme kulesinin $123 \mathrm{~m}$ doğusunda kuzey-güney yönünde akmaktadır. Dörtgen planlı yap1 büyük boyutlu bazalt taşlarla kuru duvar tekniğinde inşa edilmiştir. Kuleye giriş, güneybatı köşedeki $90 \mathrm{~cm}$ genişlikteki kap1 açıklığından sağlanmıştır. Girişin üzerindeki lentonun uzunluğu 2.30 m'dir. Kulenin en iyi korunan duvarı da arazi seviyesinden maksimum 2.60 m yükseklikte bu köşede yer almaktadır. Yapının güneybatı köşesi dışındaki duvarlar arazi seviyesinde korunmuştur. Kulenin güney duvarının $2.30 \mathrm{~m}$ güneyinde muhtemelen bir çevre duvarı olması gereken bir duvar daha $5.20 \mathrm{~m}$ uzunlukta ve yine arazi seviyesinde korunmuştur. Yapının kuzeyinde de benzer şekilde doğubatı doğrultusunda birkaç metre ilerleyen bir duvar kalıntısı vardır ki bu kalıntı da çevre duvarına ait olmalıdır. Ancak kulenin batısındaki arazi üzerinde herhangi bir duvar kalıntısı tespit edilmemiştir.

Gözetleme kulesi arkeolojik alandaki tek kalıntı değildir ve kulenin batısı ve güneyindeki arazi üzerinde, işlevlerine yönelik bir yorum yapılamayacak derecede kötü korunmuş mimari kalıntılar gözlemlenmektedir. Ayrıca kulenin $60 \mathrm{~m}$ güneyinde bir yapı kalıntısı daha tepenin doğu sınırında bulunmaktadır. Bu kalıntıya ait moloz yığını 28 x $8 \mathrm{~m}$ ölçülerinde araziye dağılmıştır. Kalıntının batı kenarında, yer yer korunmuş bir in situ duvar, arazi seviyesinde ve $14.45 \mathrm{~m}$ uzunluğunda kuzey-güney yönünde uzanmaktadır. Yapının hemen doğusundaki sarp yamacın kıyısında bitişik inşa edilmiş mekanlara dair temel duvarları gözlemlenebilmişse de arazideki yoğun ve yüksek bitki oluşumları nedeniyle sağlıklı bir çalışma bu noktada gerçekleştirilememiştir. Arkeolojik alanda az sayıda Ortaçağ seramiği ve bir-iki adet Demir Çağı'na tarihlenebilecek türden seramik parçası tespit edilmiştir. $\mathrm{Bu}$ seramik verileri, alanın kullanım dönemine yönelik kesin bir fikir edinmemize yetecek miktarda değildir. Gözetleme kulesinin duvar örgüsü, bölgedeki Erken Demir Çağı yapılarının bilinen özellikleri ile örtüşmektedir. Bu nedenle Balçeşme'nin güneyindeki bu arkeolojik alan üzerine ilk gözlemlerimiz, alanın Erken Demir Çağı'nda oluşturulmuş olduğu ve muhtemelen geç dönemlerde de kullanılmış olabileceğine yöneliktir.

\subsection{Balçeșme-Tekmezar Kulesi ve Yerleșimi (Harita 1; Resim 22-23)}

Balçeşme-Tekmezar Kulesi ve Yerleşimi, Balçeşme köyünün sinırlarında, köy merkezinin $700 \mathrm{~m}$ kadar doğusundadır $\quad$ (Koordinatlar: $\quad 40^{\circ} 49^{\prime} 52.36 " \mathrm{~K}$ 42०49'59.26"D; $\quad 40^{\circ} 49^{\prime} 52.31 " \mathrm{~K} \quad 42^{\circ} 50^{\prime} 1.93^{\prime \prime} \mathrm{D}$; $40^{\circ} 49^{\prime} 51.59^{\prime \prime} \mathrm{K} \quad 42^{\circ} 50^{\prime} 1.64^{\prime \prime} \mathrm{D} ; \quad 40^{\circ} 49^{\prime} 51.71 " \mathrm{~K}$ 42 49'59.77"D). Kura Nehri’ne bağlı Tekmezar Deresi’ne ait vadinin güney kenarında, derenin $55 \mathrm{~m}$ kadar güneyinde yer almaktadır. Buradaki kalıntılar, vadi ile Kars'a doğru uzanan karayolu arasındaki düzlükte, 2180 m rakımlık arazi üzerinde, kabaca 100 x 50 m'lik bir alanda gözlemlenmektedir.

Kayalık bir zemin üzerine inşa edilmiş gözetleme kulesi yerleşim kalıntılarının hemen hemen merkezinde ve yerleşime göre birkaç metre daha üst seviyede yer alır. Diğer iki Balçeşme kulesinde olduğu gibi kulenin vadiye bakan kenarında bir duvar yoktur ve yapıya ait doğu, batı ve güney duvarlar genel olarak arazi seviyesinde korunmuştur. Korunan duvar kalıntıları ve arazi yapısından anlaşıldığı kadarıyla dörtgen planlı yapının batı duvarı maksimum $11 \mathrm{~m}$; doğu duvarı $6.80 \mathrm{~m}$; güney duvarı ise $10.24 \mathrm{~m}$ uzunluktadır. $1.60 \mathrm{~m}$ korunan yüksekliğiyle güney duvarında korunmuş duvar örgüsüne ait bazı taşların ölçüleri $1.48 \times 1.13 \mathrm{~m} ; 1.10 \times 0.60 \mathrm{~m}$ ve $0.75 \mathrm{x}$ 0.64 m'dir. Yapının duvar genişliği 1.90-2.00 m arasına değişmektedir. Yapının girişi tespit edilememiştir; ancak, kuzey ve batı kenarlardaki sarp kayalık yükseltinin varlığ girişin ya güney ya da doğu kenardan sağlanmış olmasını gerektirmektedir. Kulenin güneyi, doğusu ve özellikle batısındaki arazi üzerinde eski bir yerleşime dair kare ve dikdörtgen planlı yapılardan oluşan bir kalıntı kümesi arazi seviyesinde gözlemlenebilmektedir. Bu kalıntı grubu 20 civarında mekândan oluşmaktadır ve mekanlar daha çok kulenin batı kenarında yer almakta ve kuleden batıya doğru yaklaşık 70 m'lik bir alanı kaplamaktadır. Kule çevresinde gözlemlenen seramik buluntularının tamamı Ortaçağ'a tarihlenmektedir. Ancak mimari özellikleri kulenin Demir Çağı'nda inşa edilmiş olabileceğini bizlere düşündürmektedir. Yerleşim alanındaki yapı kalıntıları ise arazi seviyesinde oldukça kötü derecede korunmuştur. Bu yerleşim alanının Ortaçağ içlerinde mi yoksa daha erken bir dönemde mi kullanıldığı konusu çözümü beklemektedir. $\mathrm{Bu}$ alanda daha detaylı verilere ulaşabilmek için arkeolojik bir kazı yapılması gerekmektedir.

\subsection{Balçeşme-Çam Ormanı Eskiçağ Arkeolojik Alanı (Resim 24-25)}

Balçeşme'nin kuşbakışı $3.8 \mathrm{~km}$ kuzeybatısında ve Balçeşme-Kayınlık Kulesi'nin ise $2 \mathrm{~km}$ güneybatısında bir arkeolojik alan daha 2018 yılında tespit edilmiştir. Bu alan, Kayınlık Deresi'nin güneyindeki çam ormanının tam merkezindeki $2197 \mathrm{~m}$ rakımdaki bir tepe üzerindedir (Koordinatlar: $\quad 40^{\circ} 50^{\prime} 46.31^{\prime \prime} \mathrm{K} \quad 42^{\circ} 46^{\prime} 57.50^{\prime \prime} \mathrm{D}$; $40^{\circ} 50^{\prime} 44.07^{\prime \prime} \mathrm{K} \quad 42^{\circ} 46^{\prime} 58.81 " \mathrm{D} ; \quad 40^{\circ} 50^{\prime} 47.92^{\prime \prime} \mathrm{K}$ $\left.42^{\circ} 47^{\prime} 1.43^{\prime \prime D} ; \quad 40^{\circ} 50^{\prime} 47.02^{\prime \prime K} \quad 42^{\circ} 47^{\prime} 2.29 " \mathrm{D}\right)$. Büyük ölçüde tahrip durumdaki arkeolojik alanda bir duvar sırası, kuzeydoğu-güneybatı istikametinde yamuk planda uzanmaktadır. Kuzeydoğu-güneybatı doğrultusunda 127 
$\mathrm{m}$; kuzeybat1-güneydoğu doğrultusunda ise $80 \mathrm{~m}$ civarındaki bir alanı çevreleyecek şekilde inşa edilmiştir. $\mathrm{Bu}$ kalıntı iki ayrı bölüme ayrılır. Kalıntının batısındaki ana bölüm arazi koşullarına göre inşa edilmiştir ve güneybatı köşesi tepenin alt seviyelerine doğru iyice uzanmaktadır. Bu köşeden alanın kuzeydoğu ucuna kadar diyagonal uzunluk $101 \mathrm{~m}$ kadardır. Kalıntının doğusundaki ikinci bölüm hemen hemen kare planlıdır ve iç ölçüleri 30 x 28 m'dir. Bu mimari yapının duvarlarından yıkılan taşlar araziye birkaç metre genişlikte duvar boyunca dağılmıştır. Alanın özellikle batı ve kuzey duvarlarının iç cephe sıraları arazi seviyesinde korunabilmiştir. Doğu ve batı bölümü ayıran duvarın genişliği $1.90 \mathrm{~m}$ civarındadır. Kuru duvar tekniğinde inşa edilmiş duvarlar savunma yapılarında olduğu kadar güçlü tutulmamıştır. Yapıda kullanılan taşlar kaba işçilikli ve ekseriyetle küçük boyutludur. Alanda birkaç adet seramik parçası dışında küçük buluntu tespit edilememiştir. Eskiçağ içlerinde inşa edilmiş olması gereken yapının yaylacılık faaliyetleri doğrultusunda oluşturulmuş mevsimlik bir alan olması gerekmektedir.

\subsection{Durucasu-Şimşimik Kalesi (Resim 26-27)}

Durucasu köyü, Göle ilçe merkezinin karayolu ile $11 \mathrm{~km}$ kuzeydoğusundadır. Bu köyün $1.6 \mathrm{~km}$ batısında, menderes çizerek kuzey-güney yönünde akan Şimşimik Deresi'nin $120 \mathrm{~m}$ doğusunda, Erken Demir Çağı'nda inşa edilmiş olması gereken bir kale kalıntısı ufak boyutlu bir höyük üzerinde belgelenmiştir (Koordinatlar: 40 49'51.15"K 42॰42'28.70"D; $\quad 40^{\circ} 49^{\prime} 52.18^{\prime \prime} \mathrm{K} \quad 42^{\circ} 42^{\prime} 30.23$ "D; $40^{\circ} 49^{\prime} 51.75^{\prime \prime} \mathrm{K} \quad 42^{\circ} 42^{\prime} 31.07 " \mathrm{D} ; \quad 40^{\circ} 49^{\prime} 50.56^{\prime \prime} \mathrm{K}$ 4242'29.65"D). Höyüğün zirvesinde kuzeydoğugüneybatı doğrultusunda konumlanan kalenin ölçüleri, arazi seviyesinde oldukça kötü durumda korunan duvar kalıntılarından anlaşıldığı kadarıyla $44 \quad$ x $30 \quad$ m civarındadır. Yapının doğu duvarı diğer yönlerdekilere oranla nispeten daha iyi korunmuştur. Kalenin hemen güneyindeki alanda bazı kaçak kazılar tespit edilmiştir. Bu kaçak kazılardan birinde bir Demir Çağı mezarının tahrip edildiği anlaşılmaktadır. Dolayısıyla, kalenin güneyindeki bu alanın mezarlık işlevinde kullanılmış olması gerekir. $\mathrm{Bu}$ alanın da hemen güneyinde, yakın zamana ait kule biçimli bir kireç pişirme ocağı yer almaktadır. Höyük üzerinde yapılan incelemelerde herhangi bir küçük buluntu tespit edilememiştir.

\section{Sonuç}

Ardahan 2018 yılı yüzey araştırmamız sırasında ilin merkez ilçesinde ve Göle'de toplam on farklı arkeolojik alanda arkeoloji ekibimizce incelemeler gerçekleştirilmiştir. Merkez ilçedeki Bayramoğlu Kalesi, özellikle büyük boyutlu duvarlarıyla ve bölgedeki diğer kalıntılara nazaran nispeten iyi korunmuş yapısıyla dikkat çekmektedir. Ne var ki bu arkeolojik alanın bir kısmı sonradan insan eliyle bozulmuştur.

Göle'de tespit ettiğimiz arkeolojik alanlarda çözülmeyi bekleyen en ciddi sorun küçük buluntu eksikliğinden kaynaklanmaktadır. Bunun yanında tespit edilen seramiklerin, kalıntıların mimari özellikleri ile uyuşmaması da başka bir problemdir. Balçeşme civarında tespit edilen gözetleme kulelerinde ve bunların yakın çevresinde sadece Ortaçağ seramikleri gözlemlenebilmiştir.

$\mathrm{Bu}$ makalemizin genel bir değerlendirme olmasından dolayı özellikle küçük buluntuların detay özellikleri konusuna değinilmemiştir. Ancak en yakın sürede arkeoloji ekibimizce bu konuyu ele alan detaylı bir makale kaleme alınacaktır.

\section{Kaynakça}

Patacı, S. (2019). "Yeni Araştırmaların Sonuçlarına Göre Ardahan'ın Arkeolojik Buluntuları”, şurada: Ardahan Değerlemeleri-I, Ed. Doç. Dr. İhsan Kurtbaş, Nobel Bilimsel Eserler, 119-154.

Patacı, S. ve Lafl, E. (2017). "Field Surveys in Ardahan in 2016", Anatolia Antiqua 25: 115-126.

Patacı, S. ve Oral Patacı, Ö. (2018). Some Iron Age and Medieval Sites in Göle District of Ardahan, History, Archaeology, Ethnology, [S.1.], n. I: 16-30. 


\section{Ek-1: Harita ve Resimler}

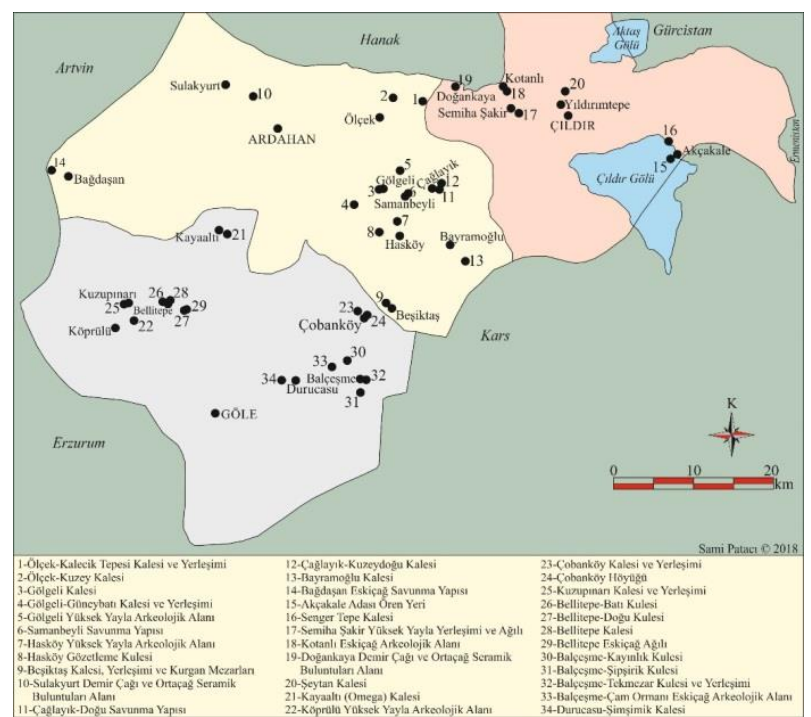

Harita 1. Ardahan'ın bazı arkeolojik buluntuları haritası.

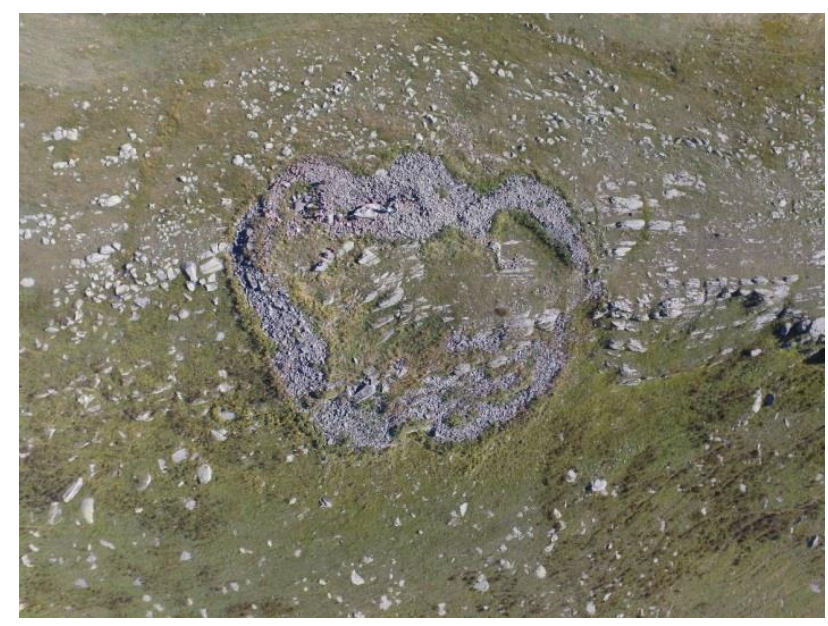

Resim 1. Çağlayık'ın doğusundaki arkeolojik alanın havadan görünümü.

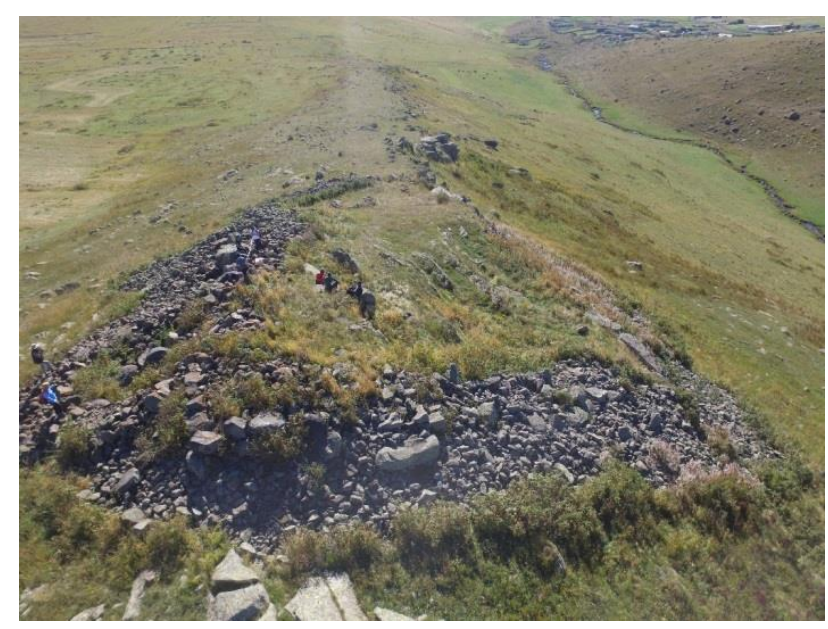

Resim 2. Çağlayık'ın doğusundaki arkeolojik alanın kuzeyden görünümü.

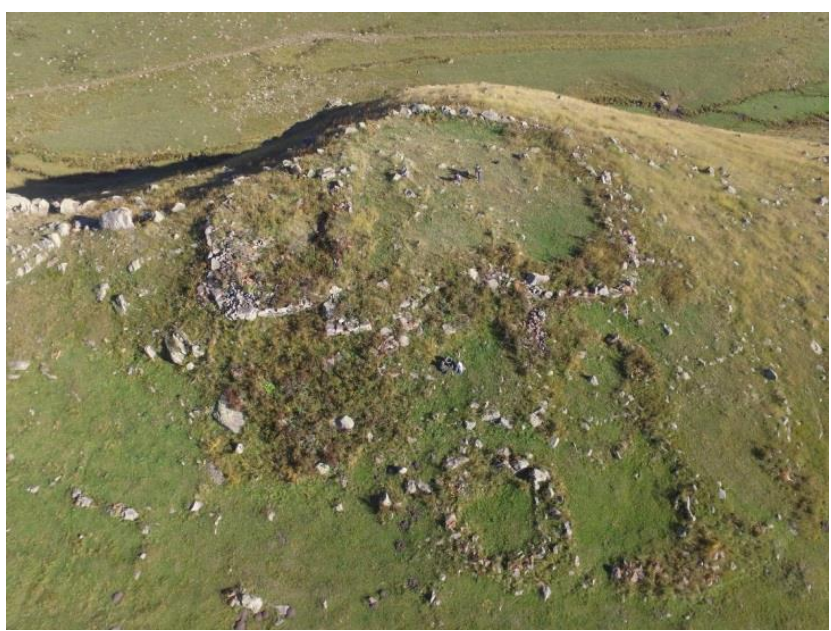

Resim 3. Çağlayık Kuzey Kalesi’nin havadan görünümü.

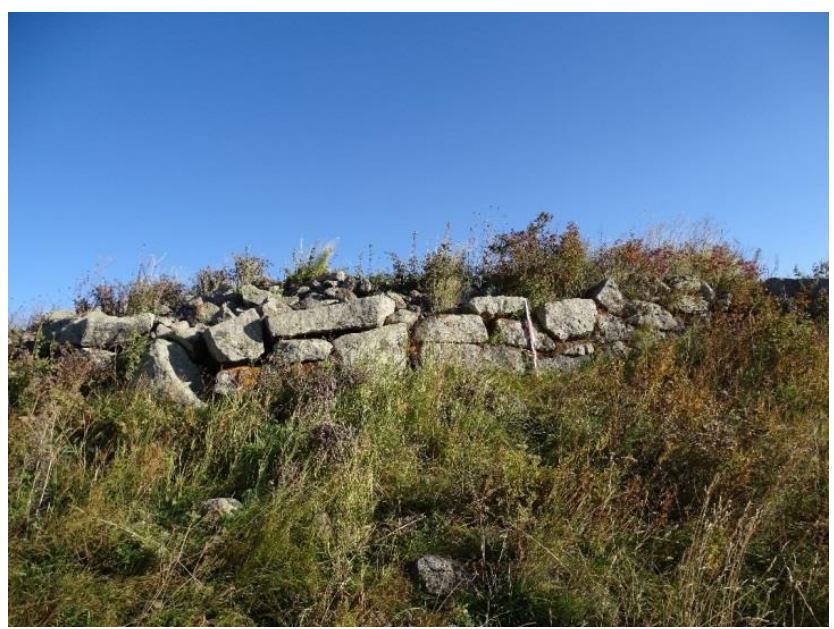

Resim 4. Çağlayık Kuzey Kalesi’nden bir in situ duvar.

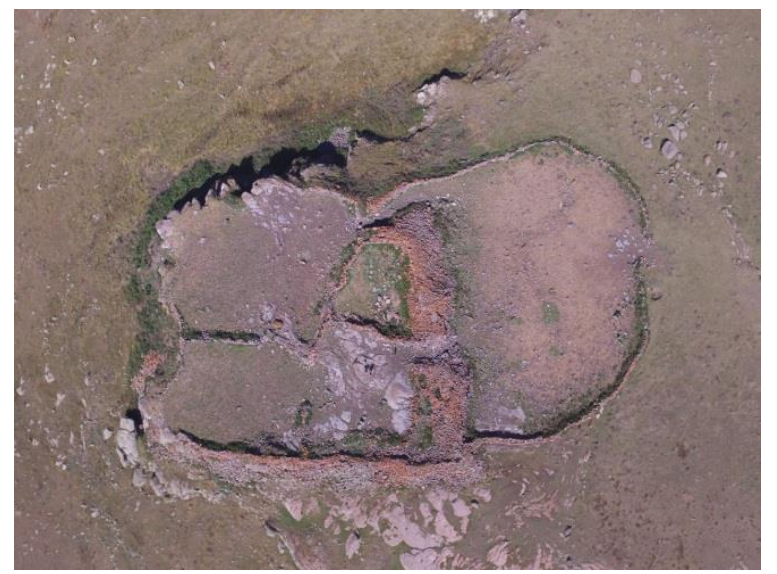

Resim 5. Bayramoğlu Kalesi’nin havadan görünümü. 


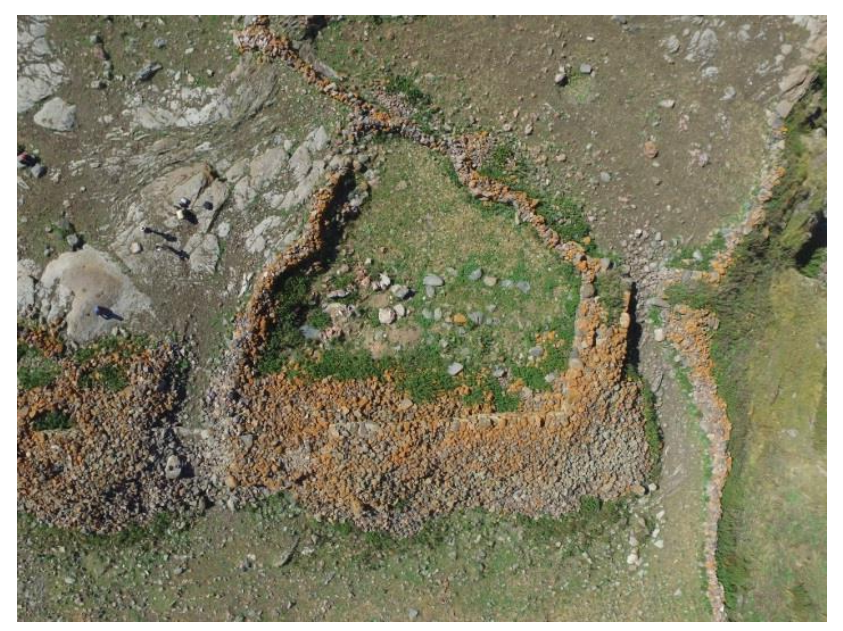

Resim 6. Bayramoğlu Kalesi'nden bir detay fotoğraf.

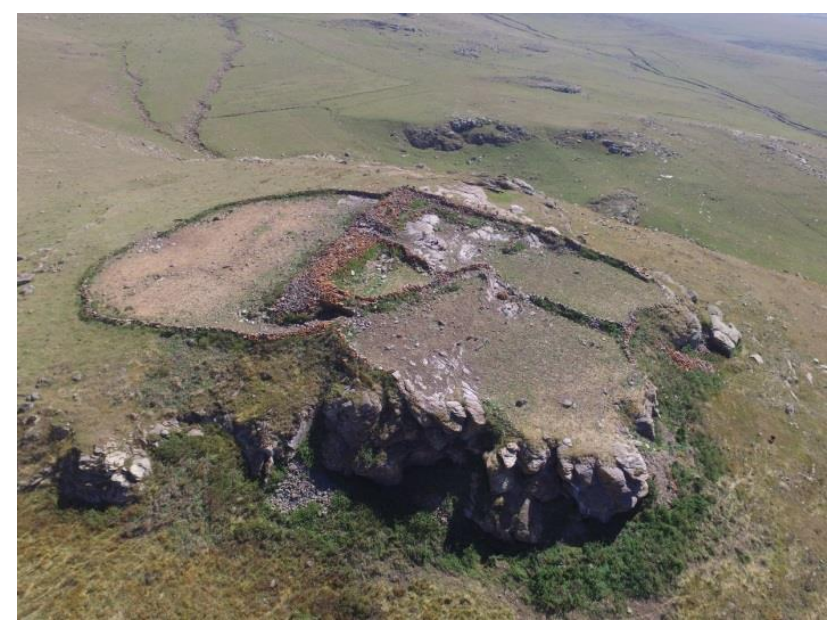

Resim 7. Bayramoğlu Kalesi’nin batıdan görünümü.

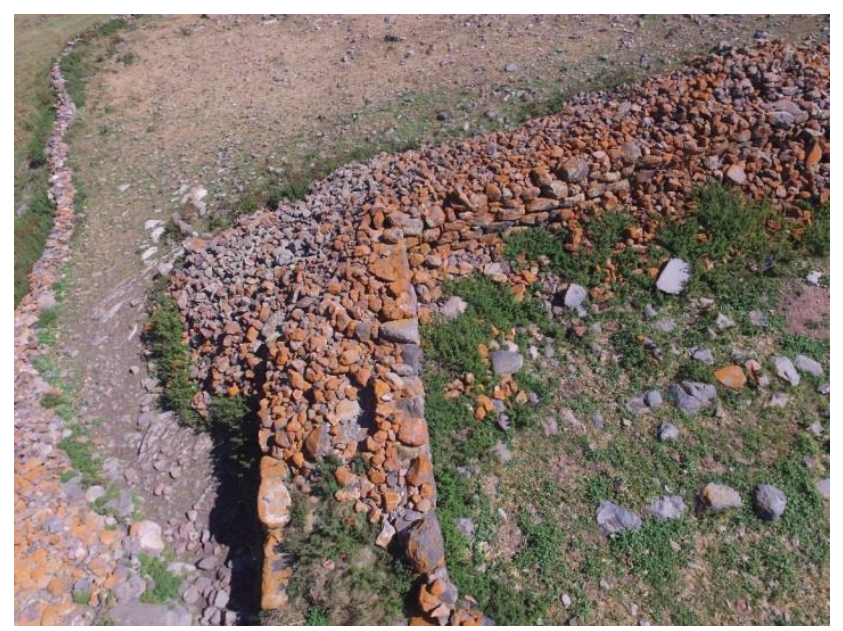

Resim 8. Bayramoğlu Kalesi’nin in situ duvarlarından bir görünüm.

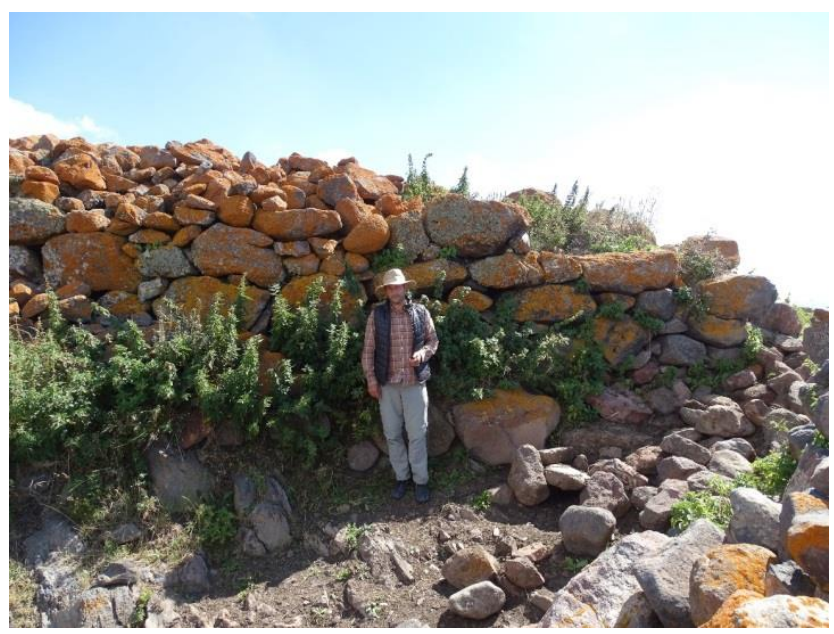

Resim 9. Bayramoğlu Kalesi'nin giriş bölümündeki in situ duvar kalıntıs1.

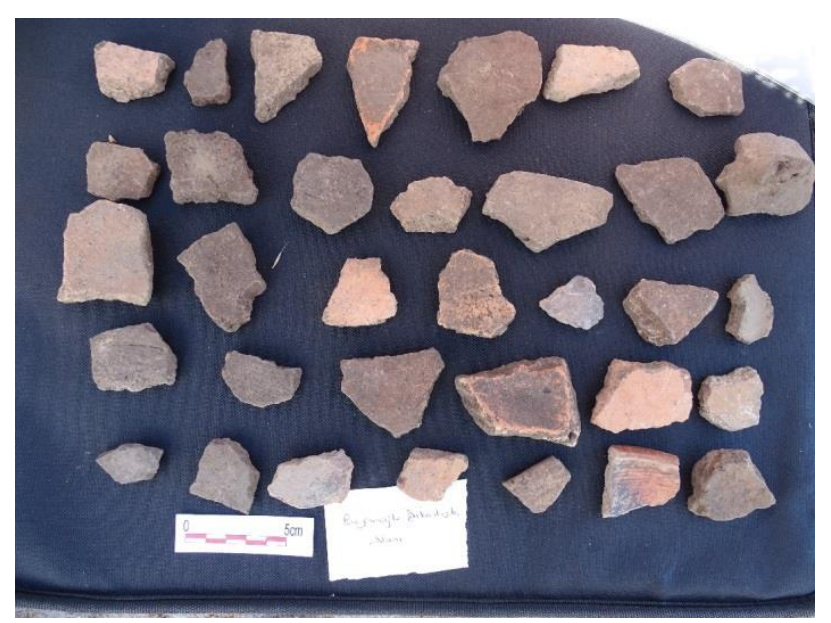

Resim 10. Bayramoğlu Kalesi’nden çanak-çömlek buluntuları.

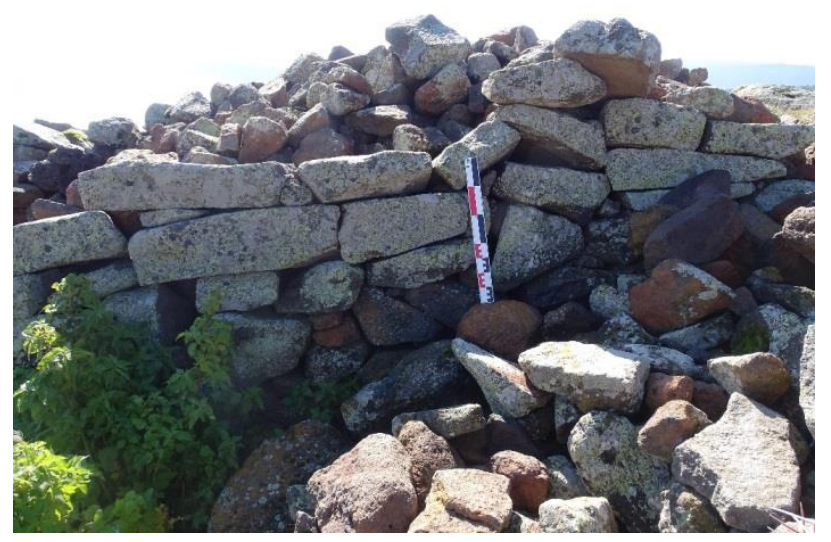

Resim 11. Bağdaşan savunma Yapısından bir in situ duvar detayl. 


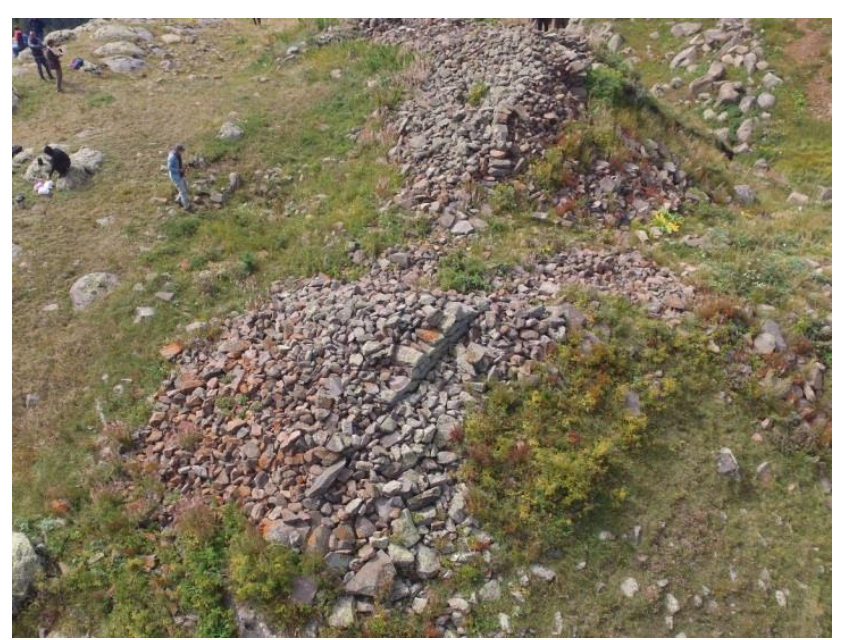

Resim 12. Bağdaşan Savunma Yapısı duvar kalıntılarının havadan görünümü.

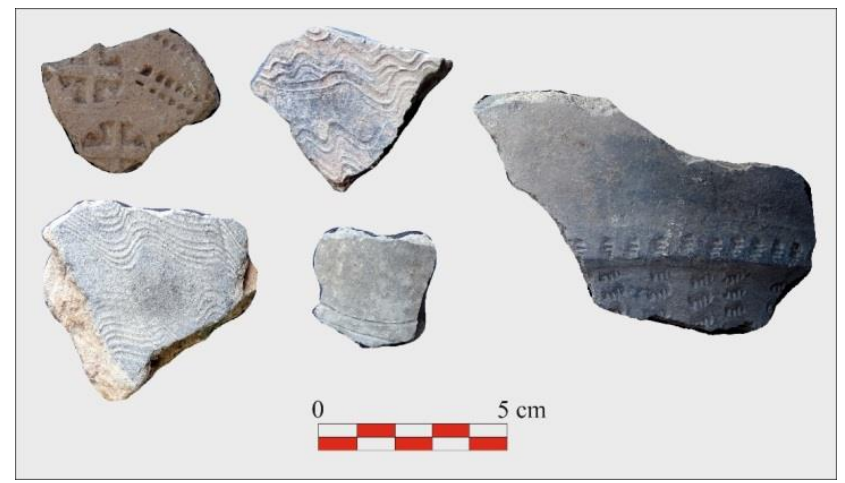

Resim 13. Bağdaşan Savunma Yapısı'ndan Ortaçağ seramikleri örnekleri.

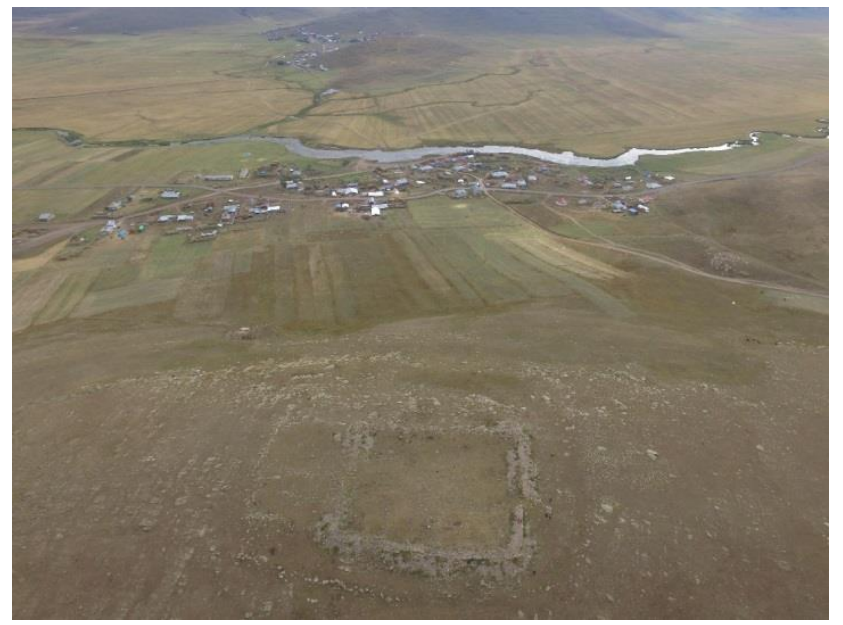

Resim 14. Bellitepe Kalesi ve kalenin güneyindeki geniş ova.

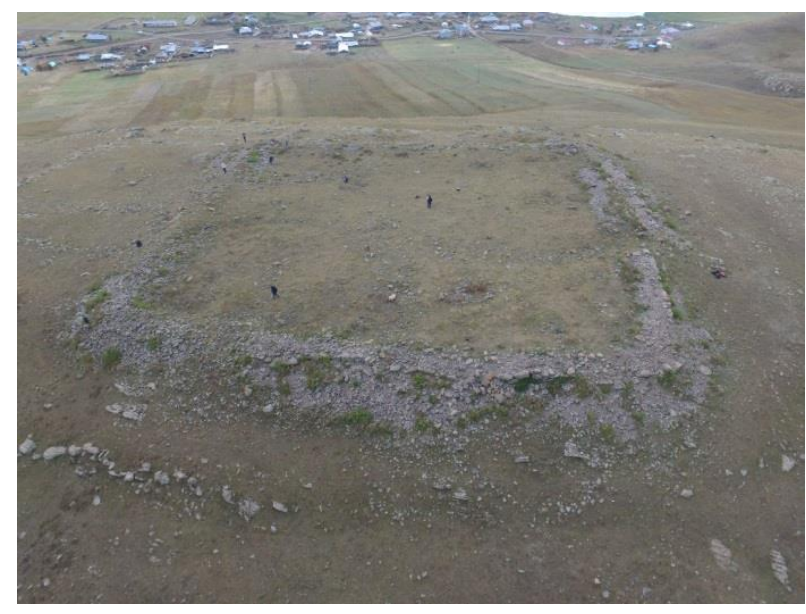

Resim 15. Bellitepe Kalesi’nin havadan görünümü.

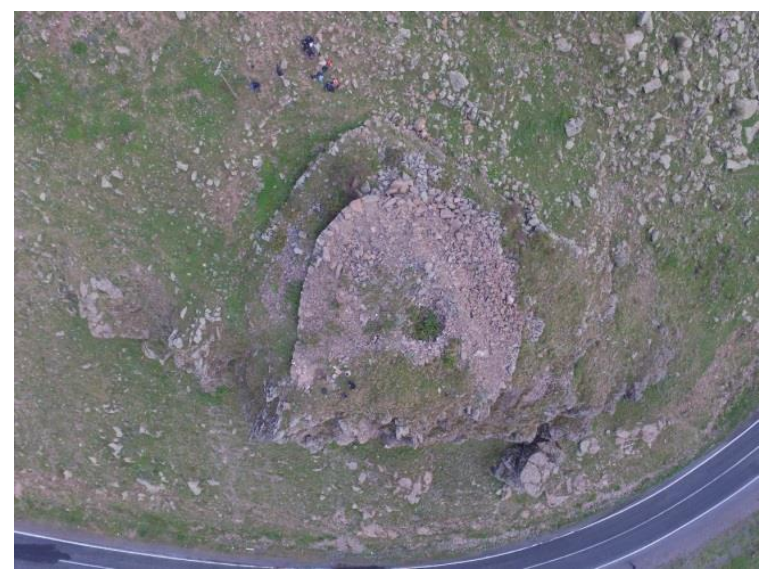

Resim 16. Balçeşme-Kayınlık Kulesi’nin havadan görünümü.

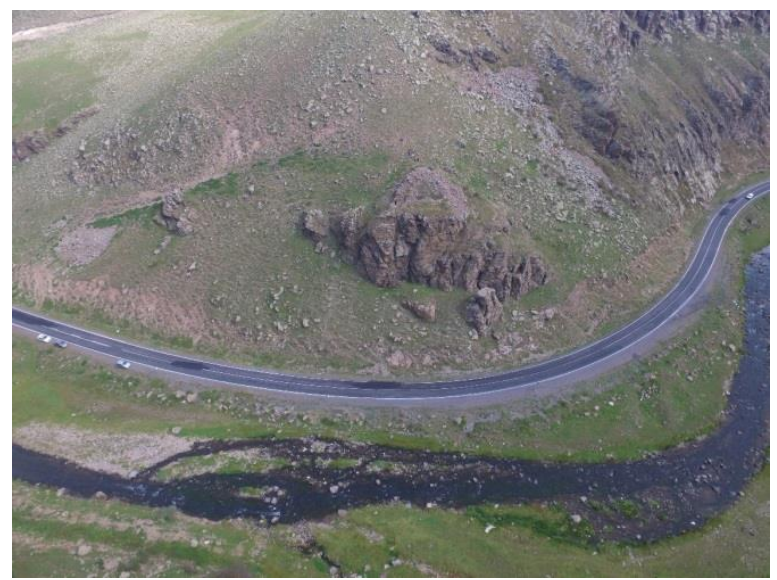

Resim 17. Balçeşme-Kayınlık Kulesi’nin üzerinde yükseldiği kayalık alan; karayolu ve Kayınlık Deresi. 


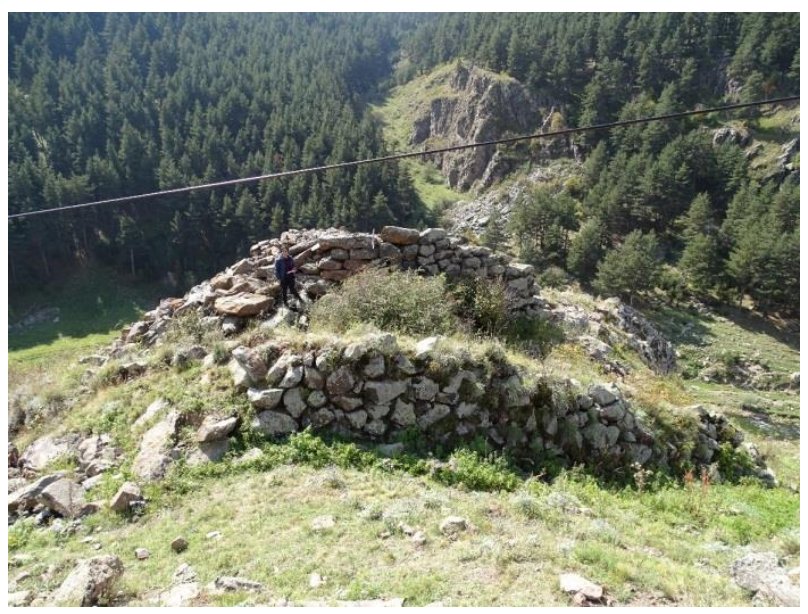

Resim 18. Balçeşme-Kayınlık Kulesi’nin kuzeyden görünümü.

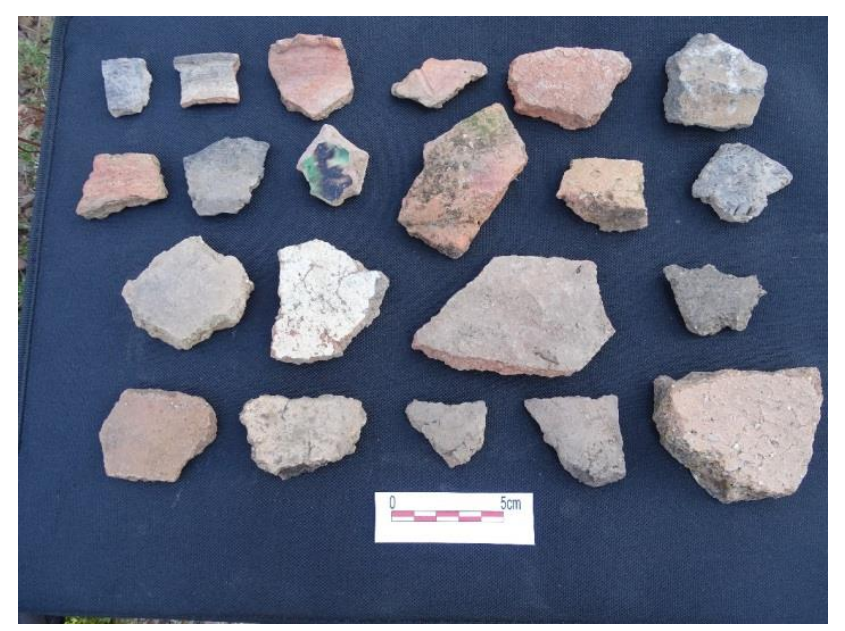

Resim 19. Balçeşme-Kayınlık Kulesi’nden bazı Ortaçağ seramikleri.

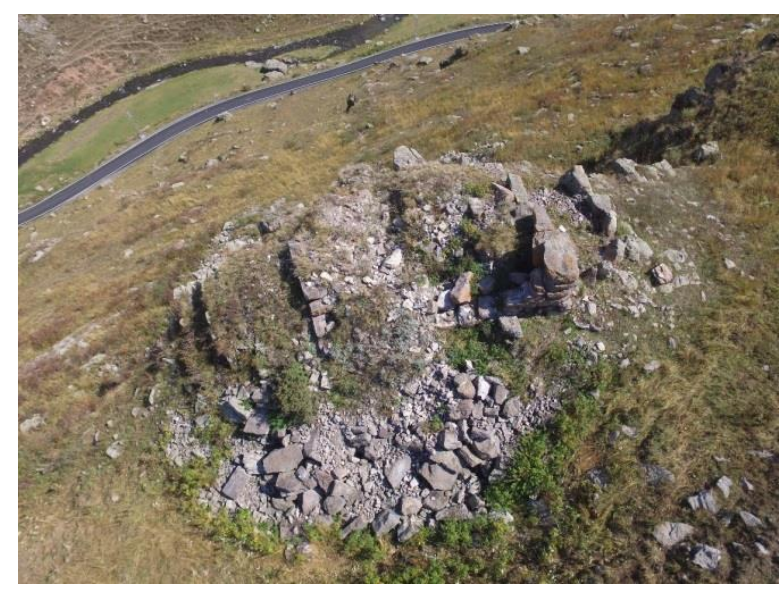

Resim 20. Balçeşme-Şipşirik Kulesi'nin havadan görünümü.

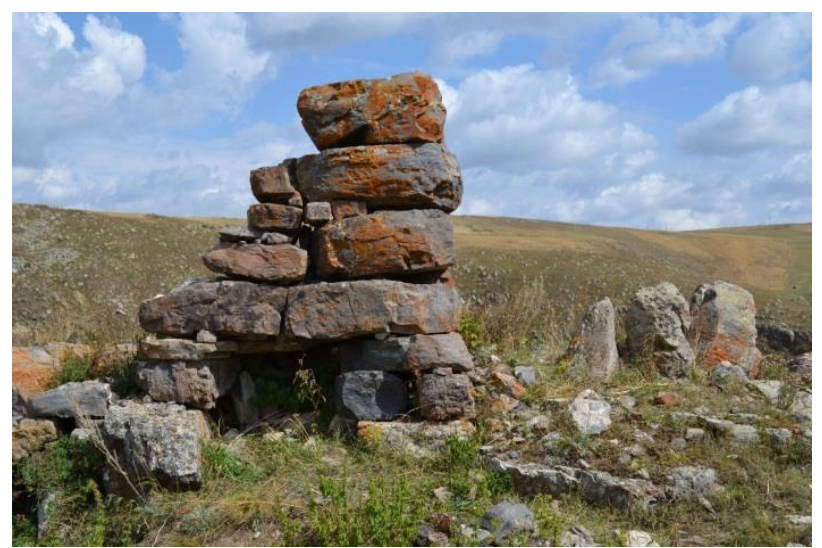

Resim 21. Balçeşme-Şipşirik Kulesi’nin giriş bölümü.

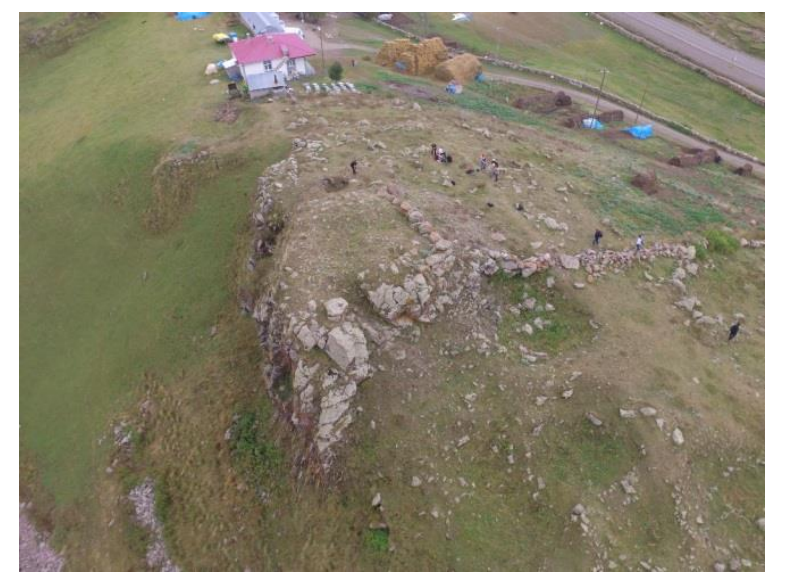

Resim 22. Balçeşme-Tekmezar Kulesi'nin havadan görünümü.

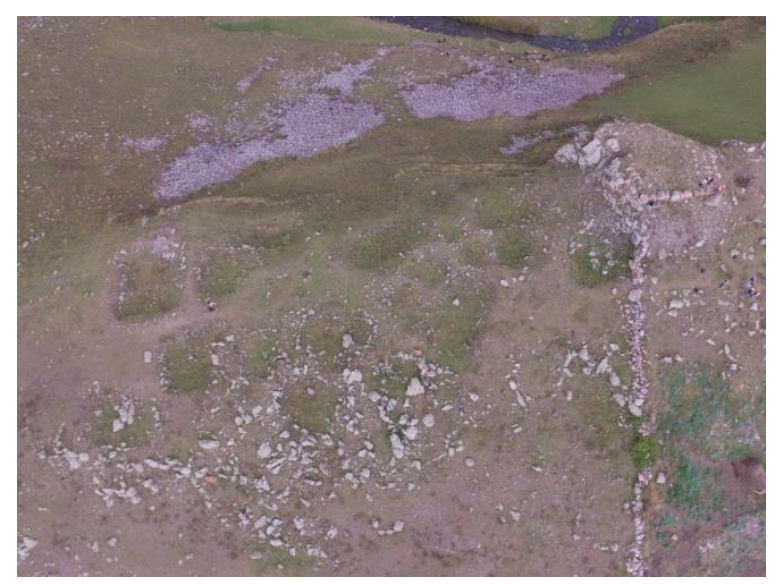

Resim 23. Balçeşme-Tekmezar Kulesi ve Yerleşiminin havadan görünümü. 


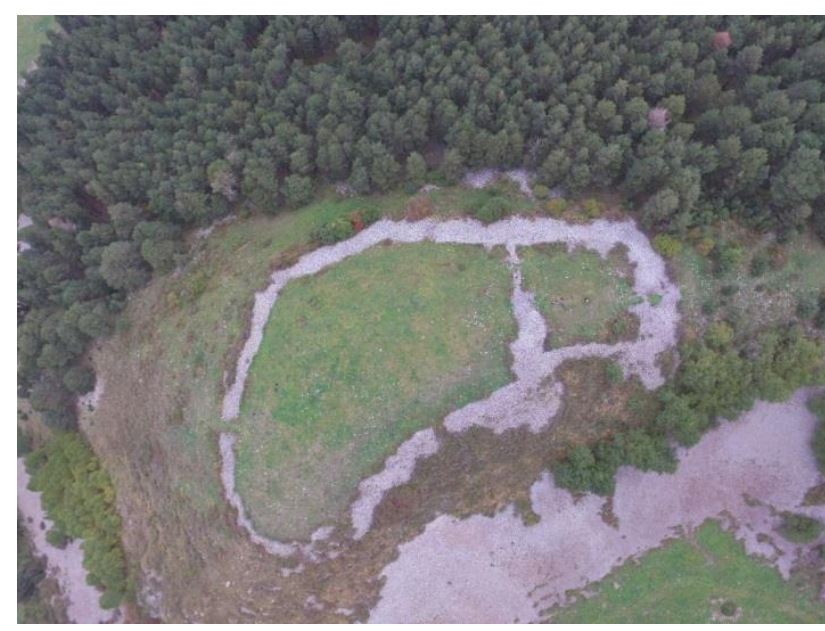

Resim 24. Balçeşme-Çam Ormanı Eskiçağ Arkeolojik Alanı’nın havadan görünümü.

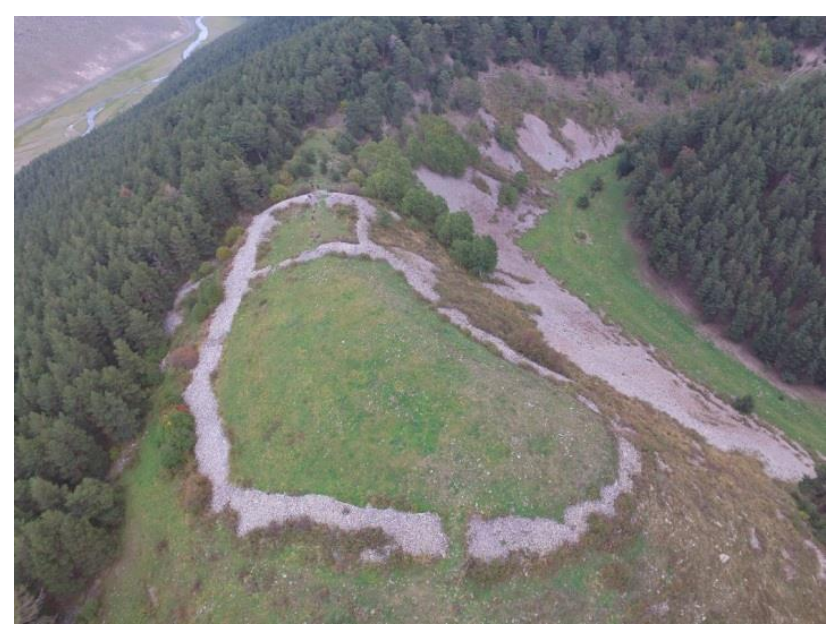

Resim 25. Balçeşme-Çam Ormanı Eskiçağ Arkeolojik Alanı'nın havadan görünümü.

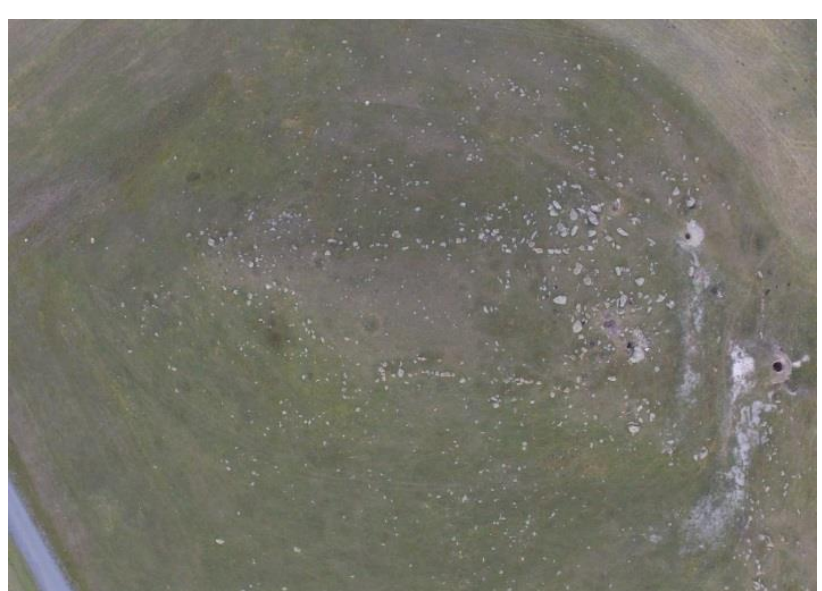

Resim 26. Bir höyük üzerinde yer alan Durucasu-Şimşimik Kalesi'nin havadan görünümü.

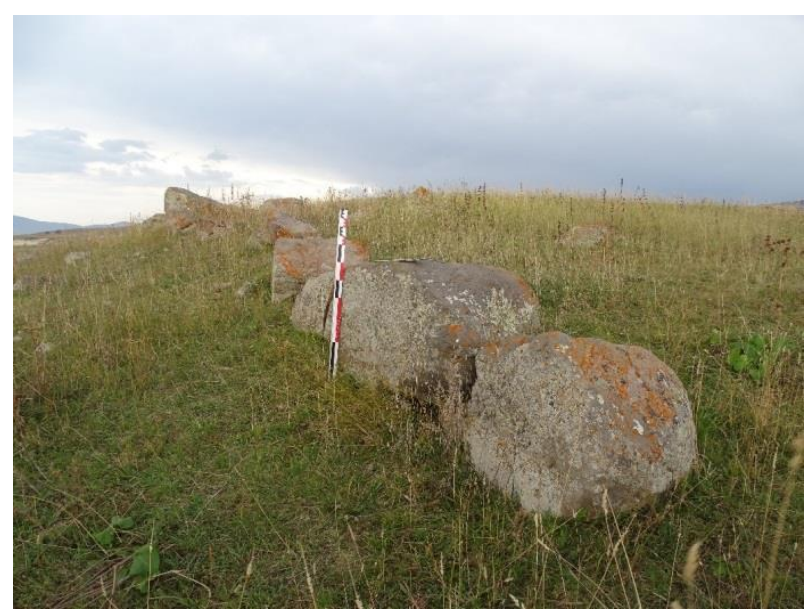

Resim 27. Durucasu-Şimşimik Kalesi'nden bir in situ duvar kalıntısı. 